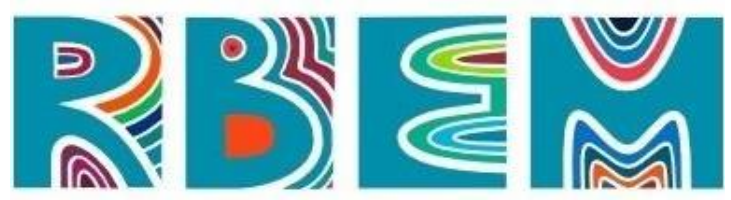

REVISTA BAIANA DE EDUCAÇÃO MATEMÁTICA

$\underline{\text { ARTIGO }}$

do/ https://doi.org/10.47207/rbem.v2i01.12146

\title{
Reconfigurando o Estágio Curricular Obrigatório em Matemática para o Contexto de Ensino Remoto Emergencial
}

\author{
ARAÚJO, Maria de Lourdes Haywanon Santos \\ Universidade Estadual de Feira de Santana (UEFS), Doutora em Ensino, Filosofia \\ e História das Ciências, https://orcid.org/0000-0002-6068-2168, E-mail: \\ lore@uefs.br \\ GRILO, Jaqueline de Souza Pereira \\ Universidade Estadual de Feira de Santana (UEFS), Doutora em Educação, \\ https://orcid.org/0000-0002-0408-047X, E-mail: jspgrilo@uefs.br
}

Resumo: A pesquisa foi desenvolvida com o objetivo de descrever o processo de reconfiguração do planejamento de dois componentes de Estágio Curricular Supervisionado em Matemática para o contexto de ensino remoto emergencial. Para tanto, apoiou-se em um estudo empírico, de abordagem qualitativa, desenvolvido na modalidade descritiva-participativa. Os resultados sugerem que, mesmo diante do contexto pandêmico, é possível o desenvolvimento dos componentes curriculares de estágio supervisionado, mediante uma reconfiguração permanente e contínua do planejamento das atividades desenvolvidas na universidade e na escola. Foi possível ainda perceber que o uso de ferramentas virtuais pode ser um auxiliar no desenvolvimento de atividades no retorno presencial, mas que elas não superam a dinâmica da sala de aula presencial, seja no Ensino Superior ou na Educação Básica, no que se refere à garantia do tempo de discussões, reflexões, convívio e, principalmente, na organização do trabalho pedagógico.

Palavras-chave: Pandemia. Estágio. Matemática. Ensino Remoto Emergencial.

\section{Reconfiguring the Curricular Compulsory Traineeship in Mathematics for the Context of Emergency Remote Teaching}

\begin{abstract}
The research was developed with the objective of describing the process of reconfiguration of the planning of two components of Curricular Compulsory Traineeship in Mathematics for the context of emergency remote teaching. Therefore, it was supported by an empirical study, with a qualitative approach, developed in the descriptive-participatory modality. The results suggest that, even in the face of the pandemic context, it is possible to develop the curricular components of Curricular Compulsory Traineeship, through a permanent and continuous reconfiguration of the planning of activities developed at the university and at school. It was also possible to notice that the use of virtual tools can be an aid in the development of activities in face-to-face return, but that they do not overcome the dynamics of the face-to-face classroom, whether in Higher Education or Basic Education, with regard to guarantee the time of discussions, reflections, socializing and, mainly, in the organization of the pedagogical work.
\end{abstract}

Keywords: Pandemic. Traineeship. Math. Emergency Remote Teaching. 


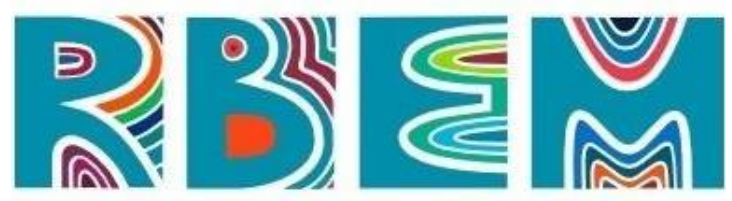

\title{
Reconfiguración de la práctica curricular obligatoria en matemáticas para el contexto de la enseñanza remota de emergencia
}

\begin{abstract}
Resumen: O resumo La investigación se desarrolló con el objetivo de describir el proceso de reconfiguración de la planificación de dos componentes del práctica curricular supervisado en Matemáticas para el contexto de la enseñanza remota de emergencia. Se apoyó en un estudio empírico, con enfoque cualitativo, desarrollado en la modalidad descriptiva-participativa. Los resultados sugieren que, incluso ante el contexto pandémico, es posible desarrollar los componentes curriculares de la práctica supervisada, a través de una reconfiguración permanente y continua de la planificación de actividades desarrolladas en la universidad y en la escuela. También se pudo notar que el uso de herramientas virtuales puede ser una ayuda en el desarrollo de actividades en el retorno presencial, pero que no superan la dinámica del aula presencial, ya sea en Educación Superior o Educación Básica, en cuanto a garantizar el tiempo de discusiones, reflexiones, socialización y, principalmente, en la organización del trabajo pedagógico.
\end{abstract}

Palavras-Clave: Pandemia. Prácticas. Matematica. enseñanza remota de emergencia.

\section{Introdução}

A pandemia provocada pelo novo coronavírus (SARS-CoV-2) e o risco de ser acometido pela doença por ele provocada, a Covid-19, mudou drasticamente a rotina da sociedade em escala mundial. Com exceção dos profissionais dos serviços essenciais, em diversos países, o home office passou a ser adotado como forma de manter as atividades econômicas e de garantir o distanciamento físico social, estratégia considerada como a mais eficiente para o controle da pandemia, até a vacinação em massa e consequente imunização da população. Para os casos em que o home office não era uma solução para a situação do empregador e do trabalhador, diferente do Brasil, países da Europa como Reino Unido e França, e da América Latina como Argentina e Venezuela, adotaram medidas governamentais que associam o controle epidemiológico com ações no campo econômico, minorando os impactos da paralisação das atividades econômicas e garantindo o direito à vida (CADÓ; BORASI, 2020).

Quando, ainda em janeiro de 2020, assistimos atônitos as notícias vindas da China, país onde foi registrado o primeiro caso da doença, não imaginávamos que um ano depois estaríamos vivenciando os efeitos do vírus mundialmente e de forma tão desastrosa e omissa como tem ocorrido no Brasil. Por meio de ações independentes e descoordenadas estamos enfrentando à pandemia embalados pelo tom das notícias econômicas - saímos da 


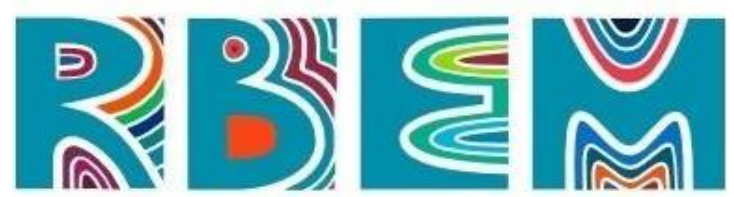

REVISTA BAIANA DE EDUCAÇÃO MATEMÁTICA

\#ficaemcasa para \#sepuderficaemcasa - assistindo passivamente o governo suspender auxílio emergencial, além das lutas constantes dos governos estaduais contra o governo federal, chegando muitas vezes ao Supremo Tribunal Federal (STF) para garantir a manutenção de ações, como fechamento de templos religiosos, manutenção de decretos de isolamento e lockdown, reabertura de leitos de UTI, liberação para compra de vacinas pelos Estados e Municípios, quando o país registrava os seus piores números decorrentes da pandemia. Em 26 de abril, o país ultrapassou a triste marca acumulada de mais mortes nos quatro meses de 2021, do que em nos dez meses de pandemia em 2020.

Que ensino é possível nesse contexto caótico? Acreditamos que essa é a pergunta que educadores ao redor do mundo têm feito. Segundo Arruda (2020), em fevereiro de 2020, o governo chinês realizou uma série de investimentos para disponibilizar aos professores e a cerca de 240 milhões de alunos acesso à conteúdos e plataformas de comunicação possibilitando o desenvolvimento de aulas por meio de programas de TV estatal, plataformas e aplicativos digitais tendo iniciado as aulas em maio do mesmo ano. Inaugura-se, em 2020, o ensino remoto emergencial como estratégia para manter professores em atividade e crianças e adolescentes em idade escolar em contato com os conteúdos escolares formais, ao passo que o sistema de monitoramento global realizado pela UNESCO, registrava, em abril de 2020, quase $90 \%$ dos estudantes fora da escola (UNESCO, 2020). Em linhas bastante gerais, diremos que o ensino remoto emergencial utiliza de aparatos tecnológicos para mediar a comunicação on-line entre professores e estudantes alternando entre momentos síncronos e assíncronos para a produção da aprendizagem, transpondo para o ambiente virtual as práticas do ensino presencial. Portanto, o ensino remoto emergencial difere da Educação à Distância $(\mathrm{EaD})$, modalidade educativa que antecede às tecnologias digitais da comunicação, exige Projeto Pedagógico específico e que segue o formato de um para muitos, numa lógica de difusão do conhecimento por meio de materiais padronizados e que a comunicação se dá majoritariamente de forma assíncrona (SANTOS, 2009).

Talvez tenhamos encontrado a resposta para a pergunta lançada: o ensino possível no contexto pandêmico é o ensino remoto emergencial. Mas, como desenvolver ensino remoto emergencial diante da exclusão digital de países como o Brasil? Dados da Pesquisa TIC Domicílios 2019, informam que apenas 37\% dos domicílios no país têm acesso simultâneo à internet e ao computador. Quando esse dado é olhado pela estratificação social, vê-se que 


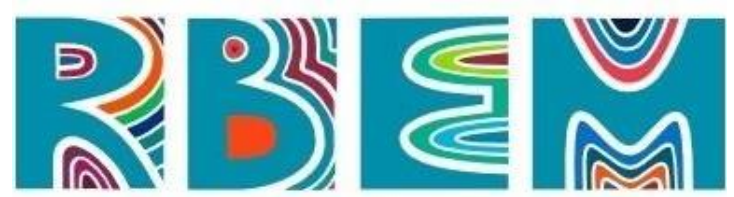

REVISTA BAIANA DE EDUCAÇÃO MATEMÁTICA

95\% dos domicílios da classe A e apenas $12 \%$ das classes D e E têm esse acesso simultâneo. $\mathrm{O}$ acesso à internet está restrito a $74 \%$ da população, sendo que o celular é o aparelho utilizado por $99 \%$ dos indivíduos (CGI.br, 2020). Além das condições de acesso ao ensino remoto emergencial, Marcon (2020) destaca a necessidade de se pensar na apropriação social das tecnologias digitais de rede, que extrapolam a noção de instrumentalização e na fluência tecnológica, ao defender uma apropriação crítica, autoral e criativa de tais tecnologias.

No contexto descrito, ancorados pelas Portaria do MEC nº 345 de 19 de março de 2020 e Resolução CEE N 27/2020 e suas alterações posteriores, tanto à educação superior quanto à Educação Básica (incluindo a Educação Infantil) adotaram o ensino remoto emergencial como forma de dar continuidade aos calendários acadêmico e escolar. Insere-se aqui a oferta de Estágios Curriculares Obrigatórios, sobre os quais pretendemos neste artigo, descrever o processo de reconfiguração do planejamento de dois componentes de Estágio Curricular Supervisionado em Matemática para o contexto de ensino remoto emergencial.

\section{Formação de Professores de Matemática: o lugar dos estágios curriculares obrigatórios}

As discussões sobre os estágios curriculares obrigatórios nos cursos de formação de professores, há algum tempo, têm requerido para os estágios um status epistemológico no sentido de superar a fragmentação teoria - prática (PIMENTA; LIMA, 2004; TARDIF, 2002). Os estágios curriculares obrigatórios se constituem como lócus privilegiado de articulação entre os cursos de formação inicial de professores e os espaços educativos formais e nãoformais, oportunizando ao futuro professor os caminhos para o desenvolvimento de sua identidade docente por meio de intervenções investigativas, reflexões críticas, planejamento, execução e avaliação de atividades atinentes a prática docente.

Compreender o processo formativo de profissionalização docente por meio dos estágios curriculares, perpassa por entender sua configuração nos cursos de formação de professores no Brasil (NOFFS; LIZARDO; SILVA, 2019). Ainda em um passado recente, os currículos de licenciatura no formato bacharelesco, onde predominava o formato $3+1$, davam o tom nas Instituições de Ensino Superior (IES) em todo o país. Na formação de professores em áreas de exatas isso se configurava ainda mais forte, em virtude do atrelamento dos professores que atuavam/atuam concomitantemente em cursos das áreas das engenharias e do 


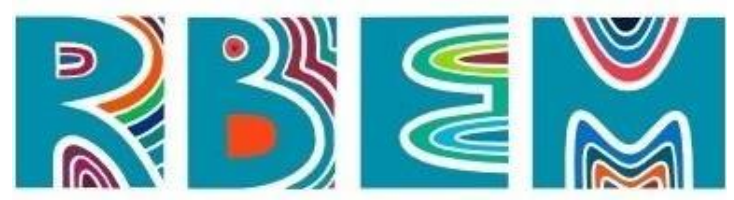

REVISTA BAIANA DE EDUCAÇÃO MATEMÁTICA

não reconhecimento da necessidade de uma formação específica para o ensinar (PIMENTA; ANASTASIOU, 2010).

Somente a partir da publicação das Resoluções CNE CP01/2002 e CNE CP02/2002 e os pareceres atrelados a tais legislações, a formação de professores começa a ter um delineamento enquanto campo de profissionalização, que deve permear todo o curso de licenciatura, com atenção específica ao espaço destinado ao estágio supervisionado obrigatório, que passa a ser definido:

[...] como o tempo de aprendizagem que, através de um período de permanência, alguém se demora em algum lugar ou ofício para aprender a prática do mesmo e depois poder exercer uma profissão ou ofício. Assim o estágio curricular supervisionado supõe uma relação pedagógica entre alguém que já é um profissional reconhecido em um ambiente institucional de trabalho e um aluno estagiário. Por isso é que este momento se chama estágio curricular supervisionado. (BRASIL, 2001, p. 10).

Passamos nesse momento de $200 \mathrm{~h}$ destinadas à metodologia e ao estágio supervisionado, ocorrendo no último ou nos dois últimos semestres do curso, para 400h dedicadas exclusivamente ao estágio e obrigatoriamente acontecendo a partir da segunda metade do curso. Isso passa a valer para os ingressantes das universidades em cursos de licenciatura por volta do ano de 2004 (ano inicial de implantação desses currículos reformulados), mas que só terá impacto nos egressos a partir de 2008, tempo de conclusão das primeiras turmas. O que queremos chamar a atenção é que mudanças educacionais levam tempo para serem implementadas e, ainda mais, para obtermos resultados efetivos e mensuráveis.

Além da mudança no estágio, as novas resoluções impõem de forma muito coerente o estabelecimento de 400h dedicadas à Prática como componente curricular, à época baseada no conceito de transposição didática (CHEVALLARD, 2013) e que deveria ocorrer desde o início do curso. Outro ponto de destaque das resoluções foi a associação do ensino e da pesquisa por meio de ações que promovessem o desenvolvimento da autonomia do discente, na perspectiva do desenvolvimento de uma identidade de professor-pesquisador para atuação na Educação Básica.

Ainda num processo de fortalecimento da formação inicial de professores, em 2015 é aprovada a Resolução CNE/CP 02/2015 que determina novas mudanças nos currículos de licenciatura. Em relação especificamente ao estágio supervisionado, não há grandes 


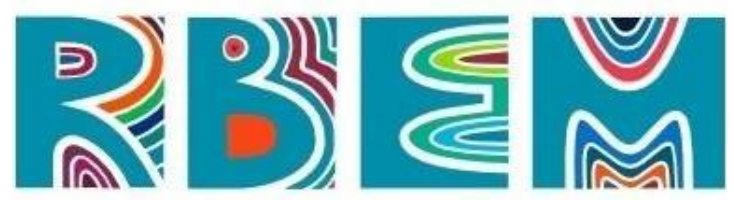

REVISTA BAIANA DE EDUCAÇÃO MATEMÁTICA

mudanças, exceto pela possibilidade em aberto do estágio ocorrer antes da segunda metade do curso e da não explicitação do aproveitamento da experiência profissional do estudante na carga horária de estágio. Nesse sentido, superando o conceito de competências da Resolução anterior, aponta para a necessidade de estabelecer uma relação intrínseca com os temas transversais, a sociologia, história e filosofia e a formação específica do licenciando e como isso repercute no fazer docente. A Resolução CNE/CP 02/2015 aponta ainda para a necessidade de se pensar uma articulação com a formação continuada e garantir as discussões mais atuais que perpassam o espaço escolar, principalmente no tocante o respeito à diversidade (gênero, raça, religião, faixa geracional), os diferentes níveis e modalidades de ensino e o uso de tecnologias, mudanças garantidas nas reformas curriculares ocorridas em todos os cursos de licenciatura da instituição (ARAÚJO; MUSSI; OLIVEIRA, 2019).

Apesar da Resolução destacar a necessidade de adequação dos currículos dos cursos de formação inicial de professores no que diz respeito ao uso de tecnologias, o estudo de Marcon (2020) destaca que menos de 50\% dos professores cursaram uma disciplina sobre o uso de tecnologias na aprendizagem durante a graduação e que esta é uma média que se mantém ao longo dos anos sem apresentar uma tendência de crescimento. Ainda no estudo é possível ver que entre os professores de Matemática esse valor chega a 58\%, entretanto, 56\% afirmam que no curso de formação inicial os professores falavam sobre como utilizar as tecnologias em atividades de ensino-aprendizagem, mas apenas $42 \%$ chegavam a realizar projetos ou atividades sobre o uso de tecnologias em atividades de ensino e aprendizagem.

Marcon (2020, p. 96) defende que "a formação inicial de professores não pode e não tem mais como deixar as tecnologias afastadas do currículo, como se fossem recursos extraclasse" e demonstra preocupação com o modo como essa formação tem chegado aos professores na pandemia - uma formação técnica e não pedagógica. Essa preocupação encontra sustentação em Sanchotene, Engers, Ruppenthal e Ilha (2021), quando os autores destacam que a maior proficiência digital apresentada por um grupo de 121 professores em atuação no ensino remoto esteve voltada para a utilização técnica, sendo detectadas carências quanto à utilização dessas tecnologias para fins de potencializar e apoiar estratégias pedagógicas centrada no desenvolvimento ativo do estudante.

\section{Contexto}




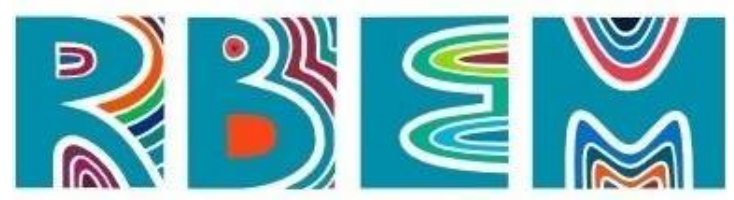

REVISTA BAIANA DE EDUCAÇÃO MATEMÁTICA

Em março de 2020, quando ocorreu a suspensão de todas as atividades educacionais presenciais no estado da Bahia, por meio do Decreto 19529/20201 do Governo do Estado, em virtude da pandemia de Covid-19, a universidade se encontrava em fase de finalização de um semestre letivo e em preparação para o início, em final de abril, do semestre 2020.1. A pandemia trouxe para esse contexto, de forma intempestiva, a necessidade de estabelecermos estratégias que permitissem a continuidade do semestre em curso, sob o risco de perdermos cerca de 90 dias letivos realizados no modo presencial. Em meio ao desconhecimento e a incerteza do que estávamos vivendo e ainda sem orientação/formação institucional, tateamos entre o contato via e-mail, grupos de WhatsApp e o Diário Eletrônico para informar aos alunos os procedimentos de avaliação e finalização do semestre em andamento que acabou se estendendo até maio.

Paralelo a esse processo, e diante da dimensão que a pandemia tomava contorno no Brasil e no mundo, a instituição estabeleceu uma comissão formada por gestores e professores com experiência na UAB ou ainda em gestão do ensino de graduação para discutir as possibilidades de ensino mediado pela tecnologia. Após diversas reuniões, aplicação de questionários a toda a comunidade acadêmica e discussão nos Conselhos Superiores, algumas ações foram estabelecidas na perspectiva de garantir um retorno às atividades num modelo de ensino remoto, como: Oferta de cursos de formação para os professores com temáticas variando entre uso de plataformas e ferramentas digitais de comunicação, metodologias de ensino e avaliação; realização da Jornada Universitária, com envolvimento da comunidade acadêmica na promoção e participação em diversas palestras e cursos, além da formalização de um semestre extraordinário completamente remoto, num período mais curto e sem obrigatoriedade de participação tanto de professores quanto de alunos.

Uma das discussões mais importantes em todo esse movimento, consistiu no entendimento dos termos remoto, híbrido, presencial e EAD, suas diferenças e nuances (MOREIRA, SCHLEMMER, 2020; CASTIONI, 2021), o que desencadeou a resistência de entidades e setores institucionais e findou com o fortalecimento do posicionamento institucional de manutenção de seus projetos de curso presenciais, a não adequação à EAD. $\mathrm{O}$

\footnotetext{
${ }^{1} \mathrm{O}$ decreto foi renovado com prorrogações que manteve a suspensão de atividades presenciais até junho de 2021, quando da finalização do presente artigo.
} 


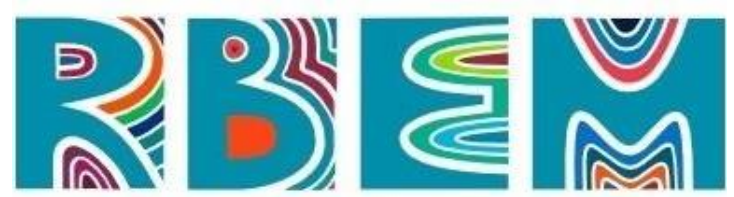

REVISTA BAIANA DE EDUCAÇÃO MATEMÁTICA

entendimento institucional é de que o formato remoto é emergencial e nesse contexto é a única possibilidade de manutenção das atividades acadêmicas enquanto não tivermos garantia de imunização por meio de vacina.

O semestre extraordinário durou de agosto a novembro, e serviu como experiência para parte da instituição que aderiu a essa proposta, resultando na aprovação de um semestre regular que teve início em fevereiro de 2021, completamente remoto. Em se tratando especificamente dos estágios obrigatórios das licenciaturas, não foram ofertadas turmas no semestre extraordinário, mas, no semestre regular, foram ofertadas quase que integralmente em todas as licenciaturas.

Nas discussões de planejamento do semestre regular remoto, a Comissão de Estágio das Licenciaturas, ponderou sobre os benefícios e prejuízos para os estudantes, principalmente pelo encadeamento de pré-requisitos das disciplinas de estágios nos vários cursos da instituição, e entendeu que participar desse momento seria um espaço para a aprendizagem de uma realidade que já estava sendo vivenciada por diversos professores na Educação Básica. A comissão definiu pela oferta dos estágios, integralmente no modo remoto, por entender que o estágio integra o corpo de conhecimentos do curso de formação de professores que "envolve o estudo, a análise, a problematização, a reflexão e a proposição de soluções às situações de ensinar e aprender” (LIMA; PIMENTA, 2006, p. 20)

No caso do Curso de Licenciatura em Matemática, a oferta foi garantida em sua totalidade. O componente curricular de estágio no Curso de Licenciatura em Matemática se divide em quatro disciplinas, cada uma com $105 \mathrm{~h}$, ofertadas a partir do $5^{\circ}$ semestre, sendo as duas primeiras dedicadas ao Ensino Fundamental e as duas últimas ao Ensino Médio, cada turma com no máximo 15 alunos matriculados. São organizadas de modo a garantir em cada uma delas dois encontros semanais entre a turma e o professor da disciplina. Há ainda na organização curricular uma divisão nas etapas do estágio, de modo que as disciplinas I e III são dedicadas ao conhecimento e integração do discente no tempo-espaço escolar, desde a sua organização administrativa até o trabalho pedagógico, inserindo-se como observador e coparticipante do cotidiano escolar. Nas disciplinas II e IV, o discente adentra esse espaço com a responsabilidade de assumir a regência, de forma supervisionada, em uma sala de aula do Ensino Fundamental e Médio, respectivamente.

Nesse contexto, o estudo foi desenvolvido a partir da análise da reconfiguração do 


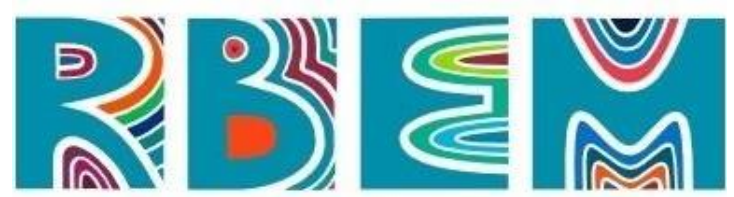

REVISTA BAIANA DE EDUCAÇÃO MATEMÁTICA

trabalho pedagógico nos componentes de Estágio Curricular Supervisionado em Matemática III e IV. Nas turmas investigadas tinham 15 e 14 alunos matriculados, respectivamente, e todos os encontros ocorreram no formato remoto. Cabe ainda destacar que, até o início de fevereiro, toda a rede pública se encontrava em atividades não formalizadas por meio de calendário oficial ou de uma orientação das secretarias municipal e estadual, funcionando por meio de ações individuais de professores ou de escolas, que se organizaram para oferta de atividades para os alunos, exclusivamente com recursos próprios. Nessa perspectiva, as discussões nos planejamentos de estágio, buscavam dar conta de um contato com escolas, seus gestores e professores, na perspectiva de parcerias que proporcionassem à Educação Básica ações as serem desenvolvidas com seus alunos e professores, em formatos diversificados como oficinas, minicursos, eventos, reforço escolar, produção de materiais curriculares, cursos de nivelamento.

Em meio a essa articulação, foi anunciado o retorno das aulas em todas as escolas, no modelo remoto, inicialmente pela Secretaria Estadual de Educação e logo em seguida pela Secretaria Municipal de Educação, para o mês de março de 2021.

\section{Percurso metodológico}

No intuito de descrever o processo de reconfiguração do planejamento de dois componentes curriculares de Estágio Curricular Supervisionado em Matemática para o contexto de ensino remoto emergencial, desenvolvemos um estudo empírico de abordagem qualitativa uma vez que, segundo Jupp (2006), os aspectos da vida social e os significados a eles atribuídos são dificilmente quantificáveis. Classificamos o estudo como descritivoparticipante, visto que pretende caracterizar com detalhes a situação estudada (FIORENTINI; LORENZATO, 2009; GIL, 2008) e, além disso, as pesquisadoras estão imersas no contexto da pesquisa (GIL, 2008).

Para a produção dos dados foram realizadas análise documental dos Planejamentos de Ensino e observação das aulas remotas emergenciais ocorridas tanto na Universidade quanto nas escolas. As observações permitiram descrever o contexto da pesquisa e identificar as situações que demandaram a reconfiguração do Planejamento.

A análise de dados empreendida considerou os três passos descritos por Gil (2008): 


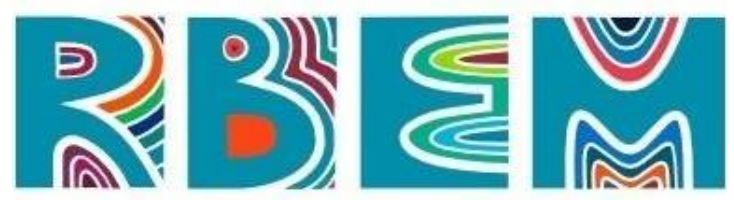

REVISTA BAIANA DE EDUCAÇÃO MATEMÁTICA

redução, apresentação e verificação/conclusão. No primeiro deles, realizamos uma seleção dos dados mais relevantes e uma pré-análise foi realizada no sentido de definir as categorias analíticas prévias do artigo. Em seguida, no segundo passo, os dados foram organizados de modo a estabelecer outras conexões entre eles, por similaridade ou diferenças, que permitiram novas descobertas sobre o objeto investigado. Por fim, na conclusão/verificação buscou-se sustentar as conclusões obtidas dos dados produzidos.

\section{Apresentação e discussão dos dados}

Pensar o estágio no curso de Licenciatura em Matemática naturalmente se constitui um desafio em virtude muitas vezes do caráter tecnicista e academicista atribuído à Matemática no Ensino Superior. Outro desafio é lidar com estudantes que desde o início do curso conseguem se inserir nas escolas de Educação Básica com os estágios remunerados, sem acompanhamento e muitas vezes reproduzindo as práticas que vivenciaram no processo de formação, como apontam Pimenta e Lima (2004).

É essencial no processo de planejamento do componente de estágio, prever os possíveis embates entre aquilo que se aprendeu, o que se ensina e como se ensina Matemática, a partir de uma perspectiva que entrelace os conceitos com a realidade social, numa perspectiva crítica. Para além do estabelecido na ementa, ampliamos os temas para o que emerge da dinâmica escolar, discutindo sempre o papel do professor de Matemática, enquanto profissional, a cada situação apresentada. Nesse sentido, a necessidade de indissociabilidade teoria - prática apontada na literatura (NOFFS; LIZARDO; SILVA, 2019; PIMENTA; LIMA, 2004; TARDIF, 2002) demanda uma reconfiguração do planejamento é uma constante para o professor de estágio.

No contexto da pandemia, essa reconfiguração assumiu contornos diversos, que levaram em consideração os aspectos apontados por Sanchotene, Engers, Ruppenthal e Ilha (2021) e Marcon (2020), principalmente, no que diz respeito ao tempo/espaço remoto, uso da tecnologia, condições habitacionais, âmbito familiar como local de trabalho e/ou de estudo. Junta-se a isso o entendimento dos tempos síncronos e assíncronos, das questões emocionais e psicológicas advindas da convivência com a Covid-19. Nesse sentido, foi necessário refletir, a partir dos planejamentos pré-existentes, frutos da realidade presencial, o que seria a prioridade 


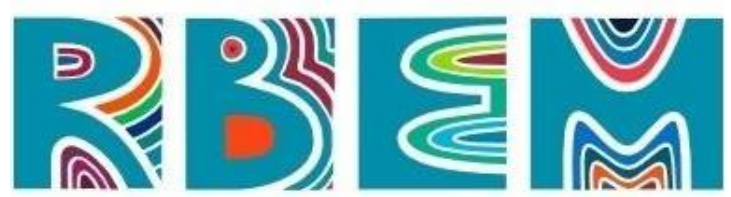

REVISTA BAIANA DE EDUCAÇÃO MATEMÁTICA

estabelecida nas ementas e, mais ainda, quais as estratégias que seriam desenvolvidas para garantirmos a aprendizagem. Assim, a articulação com a escola de Educação Básica, mesmo no modo remoto, foi priorizada e a garantia de que a etapa de campo do estágio fosse cumprida com alunos do Ensino Médio da Educação Básica.

A partir dessa prioridade, definimos os aspectos mais importantes a serem garantidos no decorrer do semestre e apresentamos as suas reconfigurações por meio de duas categorias. $\mathrm{Na}$ primeira delas descrevemos as reconfigurações realizadas nas atividades que presencialmente ocorrem essencialmente no espaço da universidade e na segunda descrevemos as reconfigurações realizadas nas atividades que no ensino presencial ocorrem essencialmente no espaço escolar.

\section{A reconfiguração das atividades desenvolvidas na universidade}

Os encontros entre os estagiários e a professora da disciplina de Estágio Curricular Supervisionado em Matemática III geralmente são organizados em três etapas não estanques, que ocorrem de forma simultânea a partir de um cronograma estabelecido no início do semestre letivo. Essas etapas visam: i) discutir temas contemporâneos da Educação (Matemática), tais como: Educação Inclusiva, Educação de Jovens e Adultos, Educação do Campo, Diretrizes Curriculares, dentre outros sugeridos pela turma; ii) discutir conteúdos matemáticos abordados no Ensino Médio por meio de aulas simuladas e análise de livros didáticos; iii) acompanhar as reflexões advindas da vivência no campo de estágio. A nossa pretensão era manter esse formato para o contexto remoto, na perspectiva de que era possível transpor aquilo que se desenvolvia presencialmente para o ensino remoto.

Contudo, como convivíamos com a incerteza do retorno das atividades escolares na Educação Básica, optamos por manter as três etapas, mas de forma não simultâneas. Ou seja, iniciamos com a etapa i) e elegemos como temas a serem discutidos: O estágio do contexto remoto; A diferença entre EAD, Educação Online, Ensino Remoto e Ensino Híbrido; Educação de Jovens e Adultos; Avaliação da Aprendizagem; Educação Comunitária e Empreendedorismo e Educação. Desses, conseguimos apenas discutir os quatro primeiros, mesmo recorrendo à confecção de Padlets nos momentos assíncronos para a sistematização de textos e/ou vídeos sugeridos. A redução da carga horária entre encontros síncronos e 


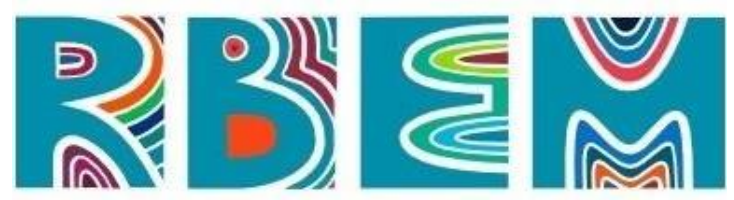

REVISTA BAIANA DE EDUCAÇÃO MATEMÁTICA

assíncronos foi um desafio constante, haja vista a dificuldade de cumprirmos a contento a programação da disciplina. Outro desafio foi lidar com as queixas dos estudantes com a sobrecarga de atividades a serem desenvolvidas e a desmotivação.

Como a turma era grande, 15 alunos, a etapa ii) foi realizada sem abrir mão de estudar todo o conteúdo do Ensino Médio por meio de Seminários sistematizados por um dos estudantes e apresentados para os demais, seguido de discussões e sugestões para o ensino. Esta etapa nos mostrou os desafios enfrentados pelos professores que precisam reinventar estratégias para expor o conteúdo que vão desde a dificuldade técnica até metodológica. Percebemos que muitos estudantes recorreram ao uso de apresentação de slides organizados de modo a fortalecer à tríade da tradição da matemática escolar: definição - exemplos exercícios. Isso nos levou a problematizar como o ensino, mesmo no contexto remoto, pode potencializar o uso de metodologias investigativas.

Antes, porém, a turma analisou os materiais curriculares disponibilizados pela Secretaria de Educação (SEC) para professores e estudantes da Educação Básica, constituído de Cadernos de Aprendizagem, Roteiros de Estudos e Pílulas de Aprendizagem. Considerando o contexto remoto, analisar esses materiais fez mais sentido do que a análise do livro didático, pois esses foram os materiais produzidos para serem entregues aos estudantes que não têm acesso à internet. Essa análise nos mostrou que eles necessitam de uma revisão, especialmente ortográfica do Caderno de Aprendizagem. Além disso, apesar da SEC ter apresentado o retorno às aulas como um continuum curricular 2020-2021, que permite cursar duas séries ou anos escolares em um ano letivo, os materiais disponibilizados não levaram em conta essa proposta e foram pensados para séries/anos regulares.

No meio deste percurso, fomos surpreendidos, no início de março, com a notícia de que as aulas na Educação Básica seriam retomadas de modo remoto. Em 15 de março as aulas foram retomadas e o Núcleo Territorial de Educação que abrange Feira de Santana (NTE -19) teve até 08 de abril para realizar as matrículas de novos estudantes. Apenas em maio, com muita dificuldade, iniciamos a etapa iii). Consideramos que nesse período as escolas estavam se organizando, tentando compreender como aconteceria esse retorno e nos limitamos a acompanhar a dinâmica das escolas por meio dos noticiários, de conversar com professores da rede, das experiências de familiares que estudam na rede. Então, a etapa que no presencial ocorre em paralelo as demais atividades, ficou programada para os meses de maio e junho e 


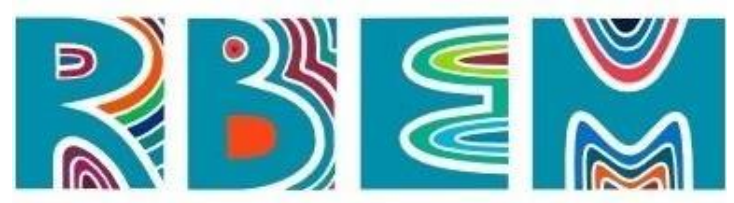

REVISTA BAIANA DE EDUCAÇÃO MATEMÁTICA

demandou outros modos de acompanhamento das atividades realizadas na escola, ocorrendo de modo assíncrono.

Para as atividades desenvolvidas com a turma de estágio IV, objetivamos atender, a partir do estabelecido na ementa, as necessidades de formação do grupo para atuação no Ensino Médio, preenchendo lacunas e articulando possibilidades de ensino tanto para o contexto remoto, quanto para o presencial. Assim, estabelecemos como prioridades os seguintes temas: Materiais Curriculares Educativos para o ensino de Matemática; A organização político pedagógica do Ensino Médio, seu objetivo e suas modalidades de Ensino; A reforma do Ensino Médio; os conteúdos matemáticos para o Ensino Médio e Avaliação Educacional (aprendizagem e larga escala).

Como os discentes já vinham da experiência do estágio em Ensino Fundamental e, no momento as escolas estavam se organizando para a retomada das atividades no modo remoto, foi possível, sem prejuízo à formação, não focar na organização e observação do espaço escolar e nas discussões de planejamento de ensino. Mesmo no contexto da pandemia, optamos por garantir que as discussões contemplassem o ensino presencial e que fosse adicionada às reflexões necessárias de adequação ao contexto remoto, corroborando a necessidade de integrar "o processo de formação do aluno, futuro profissional, de modo a considerar o campo de atuação como objeto de análise, de investigação e de interpretação crítica, a partir dos nexos com as disciplinas do curso" (PIMENTA; LIMA, 2004, p. 24).

A partir das escolhas, foi possível estabelecer os espaços de discussão, o tempo a ser dedicado a cada um deles e as estratégias a serem utilizadas nos encontros síncronos, nos encontros assíncronos e na regência, a partir das condições estabelecidas no contato com as escolas. Não podemos deixar de ressaltar que o planejamento estabelecido inicialmente, já reconfigurado para o modelo remoto, foi se modificando ao longo do semestre.

Em comparação à organização do trabalho presencial, as atividades que deveriam ser dedicadas em tempo extra ou ainda em um dos encontros semanais para as leituras de referenciais e desenvolvimento de atividades individuais, em dupla ou grupo foram transpostas para os encontros assíncronos, garantindo assim aos estudantes um tempo prédeterminado em horário estabelecido no momento da matrícula, evitando uma sobrecarga diante do contexto e dinâmica familiar. Nos horários assíncronos a professora se disponibilizava para atendimentos individuais ou em grupos a depender da necessidade 


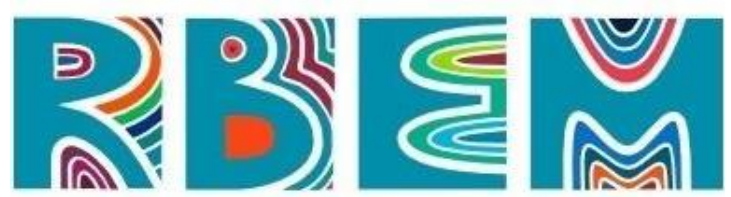

REVISTA BAIANA DE EDUCAÇÃO MATEMÁTICA

apresentada pela turma. Ainda assim, essa reconfiguração não garantiu plenamente que esse horário fosse dedicado às atividades planejadas, trazendo em alguns momentos prejuízos às discussões dos encontros síncronos.

Na reflexão dessa dinâmica com a turma, a autonomia, necessidade de organização individual e o "aprender a estudar" surgiram com muita frequência, a partir das dificuldades dos discentes em seu próprio planejamento diário/semanal, como também na dinâmica da regência com os alunos da Educação Básica, levando a inserção de um tema não planejado, o da aprendizagem autorregulada (BORUCHOVITCH, 2014; GONÇALVES, 2018).Nesse percurso, as atividades foram se desenvolvendo na construção interativa e coletiva de formulários, planejamentos da regência, rubricas de avaliação de materiais curriculares, da regência e de videoaulas, Padlets e vídeos com questões do Exame nacional do Ensino Médio (ENEM).

O estudo de conteúdos matemáticos, antes realizado por meio de microaulas, foi substituído pela confecção de vídeos com questões do ENEM, disponibilizados e avaliados pelos colegas com a rubrica criada por um dos grupos e recriada em discussão com a turma. Tal alteração não garantiu a discussão aprofundada realizada presencialmente, abordando tanto os conceitos matemáticos quanto os aspectos metodológicos de seu ensino e as diversas possibilidades de materiais curriculares educativos, sendo nesse sentido um prejuízo nessa reconfiguração, apontada inclusive pelos discentes que já haviam vivenciado essa experiência em turmas anteriores.

A reforma do Ensino Médio e os desdobramentos curriculares, pedagógicos e político, na perspectiva do objetivo desse nível de ensino, a partir do estabelecimento de suas modalidades, dominaram nossas discussões ao longo da disciplina, alimentados principalmente pelo contato com os estudantes das diversas escolas de Educação Básica do Estado da Bahia e se articulando com a discussão do ENEM como avaliação em larga escala do Ensino Médio, mas principalmente como uma das políticas de acesso ao Ensino Superior.

A discussão do papel do professor de Matemática no Ensino Médio, levou a reflexões importantes permeadas pela necessidade de compreensão que, para essa fase, para além dos cumprimento de um currículo prescrito de conteúdos matemáticos estabelecidos pelas redes de ensino, é necessária a discussão diária do momento da escolha profissional, de apresentar as diversas possibilidades existentes e orientar no desenvolvimento da autonomia que permita 


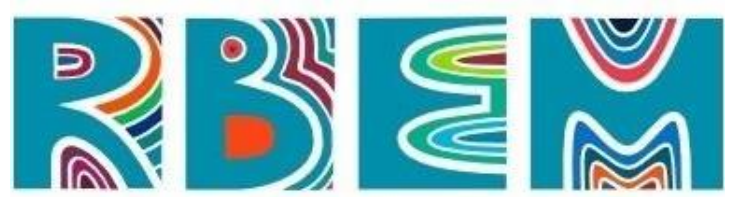

REVISTA BAIANA DE EDUCAÇÃO MATEMÁTICA

ao estudante da Educação Básica fazer escolhas que definirão os percursos profissionais a partir do término dessa etapa. Não podemos perder de vista o papel social e crítico das diversas possibilidades e o que cada uma implica em mudanças na trajetória individual e familiar, a partir das escolhas de continuidades, seja para fazer o ENEM na tentativa de acesso ao Ensino Superior, seja para os cursos profissionalizantes ou ainda a perspectiva de finalização de estudos para adentrar efetivamente o mercado de trabalho, uma vez que na realidade do nosso estado muitos jovens já trabalham nessa fase escolar. Tais reflexões foram garantidas no remoto, da mesma forma que ocorreria no presencial.

Nessa perspectiva o desenvolvimento dos dois componentes curriculares na reconfiguração das atividades desenvolvidas na universidade, apesar das dificuldades e limitações impostas pelo formato remoto, conseguiram garantir para além do cumprimento da ementa, uma apropriação do uso de tecnologias digitais no ensino com instrumentos e estratégias que podem ser utilizadas no ensino presencial, conforme estabelecido por Marcon (2020) e ainda a manutenção do que já ocorria no presencial da constante busca pela superação da dicotomia teoria-prática (PIMENTA; LIMA, 2004; TARDIF, 2002) nos espaço dos estágios curriculares.

\section{A reconfiguração das atividades desenvolvidas na escola}

O planejamento das atividades de regência, desde o momento inicial, foi pautado pela garantia de que o mesmo ocorresse por meio da articulação com a escola pública, a partir do modelo de funcionamento assumido pela gestão escolar e que garantisse que as atividades fossem desenvolvidas com estudantes da Educação Básica. Durante todo o mês de fevereiro, uma vez que não havia um posicionamento do retorno das atividades em um calendário formal presencial ou remoto, diálogos foram estabelecidos entre as professoras das disciplinas de Estágio III e IV, gestores escolares e professores de Matemática que já mantemos parceria no desenvolvimento de estágios e outros projetos como o Programa institucional de Bolsa de Iniciação à Docência (PIBID) e o Programa Residência Pedagógica (PRP), na perspectiva de compreender as atividades que estavam sendo desenvolvidas e de que modo os estágios poderiam se articular, contribuindo com a formação dos estagiários e dos estudantes da Educação Básica. Nessa fase, o estado definiu o retorno remoto das atividades formais nas 


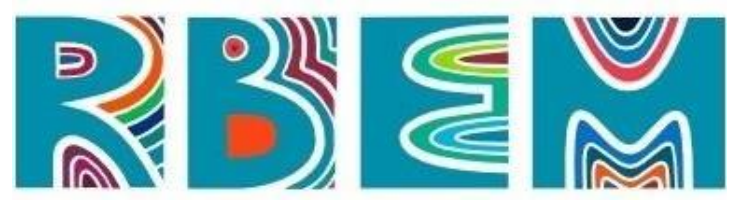

REVISTA BAIANA DE EDUCAÇÃO MATEMÁTICA

escolas no modo remoto e iniciamos o estudo da organização e documentos oficiais disponibilizados, na busca do entendimento de onde poderíamos nos inserir de modo a auxiliar as escolas, encontrando um espaço garantido na oferta das Atividades Curriculares Complementares $(\mathrm{ACC})^{2}$, destinada a ações formativas extracurriculares para garantir o cumprimento da carga horária de dois anos letivos em um ano civil.

Em estágio III, o primeiro contato com as escolas foi feito pela professora regente da disciplina de Estágio. Entramos em contato com duas escolas da rede estadual que foram muito receptivas, contudo, a principal dificuldade encontrada foi a de acesso às salas de aula. A SEC, acertadamente, disponibilizou para todas as salas de aula da rede uma sala de aula virtual em uma plataforma do Google. Nessa sala virtual foram alocados o professor e todos os estudantes matriculados, por meio do e-mail institucional (enova.educacao.ba.gov.br). Entretanto, os professores não têm gerência sobre a turma, não conseguem inserir estudantes, nem os remover, isso impossibilitou a participação dos nossos estudantes em tais salas de aula e, consequentemente, eles não conseguiam acessar a aula síncrona, pois o link utilizado era o disponibilizado na sala de aula virtual.

Para superar tais desafios, promovemos um encontro entre os estagiários e as duas professoras regentes das escolas campo de estágio. Nesse encontro, as professoras apresentaram a dinâmica remota de suas escolas, o perfil dos estudantes, as dificuldades técnicas de colegas, dentre outras questões abordadas também pelos estagiários. Diante do impasse quanto ao acesso às salas, sugerimos, em comum acordo, desenvolver Oficinas para os estudantes do Ensino Médio e as escolas se comprometeram em contabilizar a carga horária como ACC para os seus estudantes. Infelizmente, devido aos problemas técnicos, não foi possível realizarmos as observações das aulas síncronas realizadas pelos professores. Em contrapartida, a etapa prevista de coparticipação ocorreu com sucesso, haja vista que tivemos mais de 170 estudantes da Educação Básica inscritos para participar das oficinas e 94 participantes.

A oficina voltada para Análise Combinatória no ENEM, por exemplo, chegou a ter mais de 60 estudantes participando ativamente pelo chat da sala virtual e usando o microfone. Apesar de pouquíssimas câmeras abertas, a dinâmica da interação nos mostrou o interesse dos

\footnotetext{
${ }^{2}$ O desenvolvimento das ACC segue as orientações da Instrução Normativa n. 03/2021 da SEC-Bahia.
} 


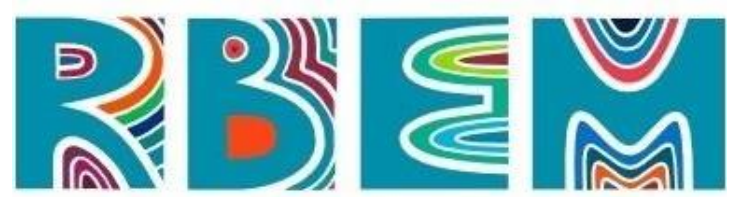

REVISTA BAIANA DE EDUCAÇÃO MATEMÁTICA

estudantes pelo tema proposto. Para coordenarmos essa dinâmica, mantivemos todas as oficinas com dois ou três estagiários, de modo que o chat pudesse ser acompanhado mesmo nos momentos de compartilhamento de telas. Com isso, avaliamos o quão difícil é para um professor controlar todas as formas de interação, estando sozinho numa sala virtual.

No Estágio IV, o planejamento inicial foi nos organizarmos em turmas de Ensino Médio, de quatro escolas públicas estaduais, com o acompanhamento de professores regentes e desenvolvermos um planejamento que garantisse uma revisão de conteúdos do Ensino Fundamental que mais seriam utilizados no Ensino Médio e uma continuidade dos conteúdos correspondentes ao ano letivo anterior de cada turma, uma vez que em 2020 e até o início do semestre em 2021, essa organização formal não estava estabelecida. Como dito anteriormente, com a definição do estado pelo retorno remoto das atividades, articulamos a possibilidade de uma transferência do que já acontecia no presencial para o remoto, como os estagiários assumindo uma turma da oferta regular das escolas, o que não se concretizou em função da complexidade na organização do espaço escolar no modelo remoto, incluindo planejamentos, uso de plataformas, matrícula dos estudantes, e compreensão da proposta de dois anos em um e a carga horária da etapa de estágio que precisava ser cumprida. No contexto presencial, geralmente estabelecemos uma ponte entre o estágio III e o IV, garantindo a realização dessa etapa no mesmo espaço escolar e com o mesmo professor regente e turma, com a inserção na escola desde o início do semestre de modo que a imersão ocorre de forma mais contextualizada e efetiva na escola e o cumprimento das $45 \mathrm{~h}$ em uma turma de Ensino Médio que destina em média $2 \mathrm{~h}$ ou $3 \mathrm{~h}$ semanais para Matemática.

A articulação ocorria a cada encontro com a turma, a partir das demandas e necessidades apresentadas pelos estagiários, a cada conversa e encontro com a escola na figura da gestão escolar e do professor de Matemática e na dinâmica institucional no diálogo com os colegas, parceiros de trabalho e pode ser compreendida na discussão apresentada na sequência.

Projetou-se que a melhor perspectiva para a turma seria a inserção nas ACC, promovendo com o Centro Juvenil de Ciência e Cultura de Feira de Santana (CJCC Feira), espaço privilegiado da oferta de atividades diversificadas na rede estadual, uma variedade de ações no Projeto, posteriormente, intitulado Diálogos Virtuais com a Matemática. Em dois encontros consecutivos, a gestão escolar e o professor regente participaram de uma de nossas 


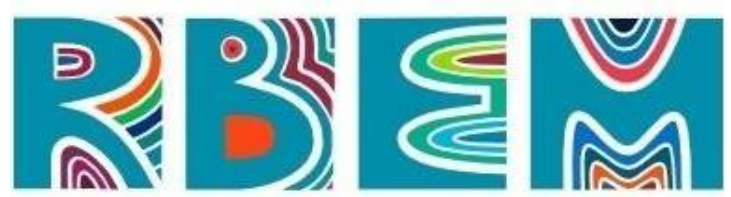

REVISTA BAIANA DE EDUCAÇÃO MATEMÁTICA

aulas para apresentação da escola e sua proposta pedagógica, ao tempo em que apresentamos nosso projeto. Os ajustes foram realizados a partir das necessidades das instituiçõos e do que acreditávamos ser necessário para os estudantes do Ensino Médio que se encontravam a quase um ano sem uma rotina diária de estudos.

Planejamos então a oferta de múltiplas atividades (Oficina, Minicurso, Palestras, Simulados, Reforço Escolar, Cursinho Preparatório para o ENEM) com os principais conteúdos de Matemática do Ensino Médio (Funções, Análise Combinatória, Trigonometria, Matemática Financeira, Logaritmos, Probabilidade e Estatística) e publicizamos por meio de vídeo e card de divulgação apresentando cada atividade e a inscrição no formato de Padlet ${ }^{3}$.

Nosso maior desafio era garantir a formação de turmas para cada atividade uma vez que a escola não é organizada no formato de turmas regulares, mas por iniciativa do próprio estudante em participar. Por outro lado, isso em grande parte garante que os participantes se insiram nas ações com determinação, esforço e necessidade em buscar outros espaços de ensino e de aprendizagem.

As atividades ocorreram de abril a junho de 2021, com turmas simultâneas ao longo da semana, em diversos horários, com os estagiários assumindo integralmente a atividade organizada em duplas ou trios, de forma a assegurar apoio e suporte entre os professores em formação e o atendimento aos estudantes da Educação Básica nas perguntas e dúvidas evidenciadas nas participações seja no chat ou ao "abrir o microfone".

É importante ressaltar que, do mesmo modo que no presencial, as discussões nos encontros síncronos repercutiram nos planejamentos nos temas das atividades e nos diálogos estabelecidos com os estudantes da Educação Básica, principalmente no tocante às diversas orientações sobre a autonomia para a aprendizagem e no acesso ao Ensino Superior por meio do ENEM.

Não podemos deixar de registrar que a Covid-19 permeou a grande maioria de nós ao longo do semestre seja pelo contexto de tantas perdas no Brasil e no mundo e seus impactos sociais, político e econômico, mas de forma mais efetiva na testagem positiva de alguns de nós, de nossos familiares, inclusive em contextos de gravidade com internamento e óbitos. Foi o esforço do coletivo e da colaboração entre colegas que garantiu que todo o processo não se refletisse na dinâmica de oferta das atividades.

\footnotetext{
${ }^{3}$ Para visualização das atividades acessar https://padlet.com/estagiomatematicauefs/ghj38g6xgh4rt2o6
} 


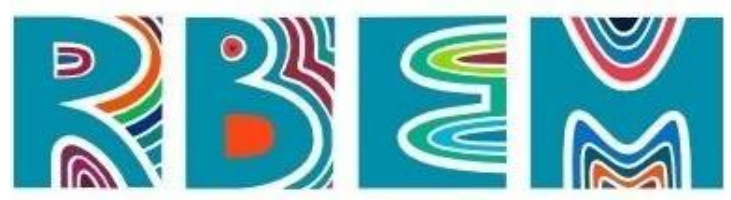

REVISTA BAIANA DE EDUCAÇÃO MATEMÁTICA

Outra situação ocorrida que exigiu uma nova reconfiguração foram dois casos de estagiários que ofertaram mais de uma turma de suas atividades e não tiveram inscritos, ou ainda os inscritos não compareceram. Nesses casos, como a organização escolar da oferta regular já se encontrava mais adiantada e esses estudantes estavam em contato com a escola em estágio remunerado ou com a PRP, estabelecemos um diálogo com os professores supervisores/preceptores para o desenvolvimento do estágio em outras turmas da escola, o que foi acolhido e desenvolvido sem interrupções.

Todas as atividades desenvolvidas foram planejadas e disponibilizadas para o CJCC, utilizando formulários próprios da escola e sendo reconfiguradas a cada encontro a partir da demanda da turma inscrita e do diálogo constante nos encontros síncronos. Uma das maiores dificuldades foi estabelecer o primeiro contato com os estudantes inscritos. Inicialmente tentamos o envio de links e avisos pelo e-mail disponibilizado na inscrição por cada estudante por consideramos uma estratégia mais formal, mas não obtivemos muito sucesso. Não tínhamos retorno e na primeira semana poucos compareceram. Optamos então pelo contato via WhatsApp, em uma conta criada especificamente para tal por um dos estagiários, que se disponibilizou para o envio dos links, incentivo a participação, dialogando e tirando dúvidas dos estudantes. Esse canal se mostrou mais efetivo e os estudantes passaram a frequentar efetivamente as ações.

Ainda no início do semestre a Universidade abriu inscrições de Monitoria Voluntária para os Cursos de Graduação e uma das discentes da turma se disponibilizou. O processo de monitoria foi essencial no suporte diário ao andamento das atividades de estágio, uma vez que assumiu a dinâmica de elaboração de formulários, controles de frequência e auxílio no planejamento e acompanhamento junto com a professora nas atividades da regência. $\mathrm{O}$ acompanhamento de todas os estagiários se tornou um ponto de sobrecarga na efetivação do Estágio IV, uma vez que tínhamos apenas um professor regente para todas as turmas e o mesmo em função dos desdobramentos da Covid-19 em seu âmbito familiar, não conseguiu fazer o acompanhamento, sendo esse assumido exclusivamente pela professora da disciplina e pela monitora supracitada, o que não ocorreria no presencial uma vez que a escola, para além do professor regente, dispõe de vários professores, coordenadores e direção para esse acompanhamento.

Com número alto de inscritos nas atividades (cerca de 100 estudantes no total), mas 


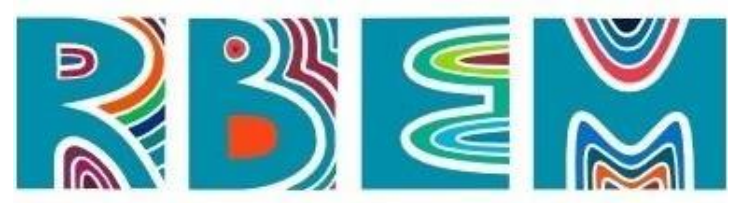

REVISTA BAIANA DE EDUCAÇÃO MATEMÁTICA

com baixa participação (em média, 6 a 10 em cada turma), investigamos as prováveis causas da frequência e identificamos principalmente o choque de horários entre as atividades do Projeto e os encontros síncronos nas suas respectivas escolas, trabalho e demandas dos cuidados de casa. Entretanto, é possível destacar o interesse e participação efetiva dos estudantes que cursaram as atividades, tirando dúvidas e interagindo com os estagiários em grande parte dos encontros o que permaneceu por três meses em todas as atividades do Projeto.

As maiores dificuldades encontradas na execução das atividades, ocorreram principalmente pela limitação no uso das tecnologias para o ensino de Matemática de modo expositivo, corroborando os resultados apontados por Sanchotene, Engers, Ruppenthal e Ilha (2021) e Marcon (2020). A dificuldade em se desprender do quadro-giz e mais ainda, a percepção da necessidade essencial de se fazer Matemática na tradição da Matemática: definição-exemplo-exercícios, reforça para nós professores, como o espaço da sala de aula, presencial interfere no ensino e, consequentemente, na aprendizagem da Matemática. Diversas estratégias foram aplicadas, desde o uso de mesa digitalizadoras, Power point, Jam, Apps que simulam o quadro, canetas para telas touch, paredes de casa forradas com papel para serem riscadas ou ainda um quadro branco ao fundo do espaço de aula. Essa limitação também repercute na dificuldade de escrita (pelos estagiários) e de visualização pelos estudantes, seja pelo traço inconsistente da escrita digital ou ainda pela limitação da tela do celular, muito pequena para perceber uma resolução de exercício na íntegra, por exemplo.

A rubrica de avaliação das atividades criadas de modo coletivo, discutidas e recriadas nos encontros síncronos e assíncronos foi convertida num questionário no Google Forms e disponibilizada a todos os participantes do Projeto, tanto nas atividades do Estágio IV quanto do Estágio III. Essa ação trouxe para nós um componente da avaliação do estágio que geralmente no presencial não é inserido que é a perspectiva do estudante na avaliação do estagiário. Essa novidade provavelmente será incorporada no retorno presencial, pois agrega à avaliação do componente curricular o olhar do aluno da Educação Básica, o elo que mais interage com o estagiário na sala de aula durante todo o desenvolvimento da regência.

Assim, a reconfiguração das atividades desenvolvidas na escola, garantiu a continuidade do estágio curricular obrigatório articulado com as escolas públicas, contribuindo com a formação inicial do professor de Matemática e com o ensino de 


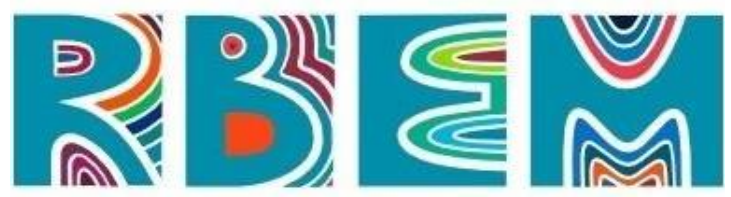

REVISTA BAIANA DE EDUCAÇÃO MATEMÁTICA

Matemática na Educação Básica, num processo contínuo de aprendizagem. Além disso, possibilitou o reconhecimento de limitações do contexto virtual e, no caso dos estagiários que já haviam realizado estágio no formato presencial, a comparação entre os dois formatos.

\section{Considerações Finais}

Desenvolver este estudo com o objetivo de descrever o processo de reconfiguração do planejamento de dois componentes de Estágio Curricular Supervisionado em Matemática para o formato de ensino remoto emergencial, nos permitiu concluir que, mesmo diante do contexto pandêmico, é possível o desenvolvimento desses componentes curriculares. Entretanto, destacamos que não é possível uma simples transposição das ações que ocorrem no presencial para o ensino remoto, haja vista que tanto a Universidade quanto as escolas estavam vivenciando uma nova forma de ensinar, requerendo do Estágio a imersão em novas possibilidades formativas. No quadro 1 a seguir, sintetizamos como se deu o processo de reconfiguração.

Quadro 1. Síntese do processo de reconfiguração de duas turmas de Estágios Curriculares Obrigatórios em decorrência do ensino remoto emergencial

\begin{tabular}{|c|c|c|}
\hline $\begin{array}{l}\text { Componente de Estágio / } \\
\text { Súmula da ementa }\end{array}$ & Configuração no ensino presencial & $\begin{array}{l}\text { Reconfiguração para o ensino remoto } \\
\text { emergencial }\end{array}$ \\
\hline $\begin{array}{l}\text { ESTÁGIO CURRICULAR } \\
\text { SUPERVISIONADO EM } \\
\text { MATEMÁTICA III } \\
\text { - Estudos, reflexões e discussões } \\
\text { referentes à organização do } \\
\text { espaço e tempos escolares, da } \\
\text { organização da escola de } \\
\text { ensino médio e suas } \\
\text { modalidades de ensino. } \\
\text { Participação em elaboração de } \\
\text { projetos pedagógicos. } \\
\text { - Observação do cotidiano da } \\
\text { sala de aula de Matemática e } \\
\text { participação in loco. } \\
\text { - Aspectos históricos, didáticos e } \\
\text { psico-sociológicos relativos a } \\
\text { tópicos do conhecimento } \\
\text { matemático trabalhado no } \\
\text { ensino médio. } \\
\text { - Análise crítica de livros } \\
\text { didáticos. A do ensino } \\
\text { - Avaliação do } \\
\text { aprendizagem em Matemática. }\end{array}$ & 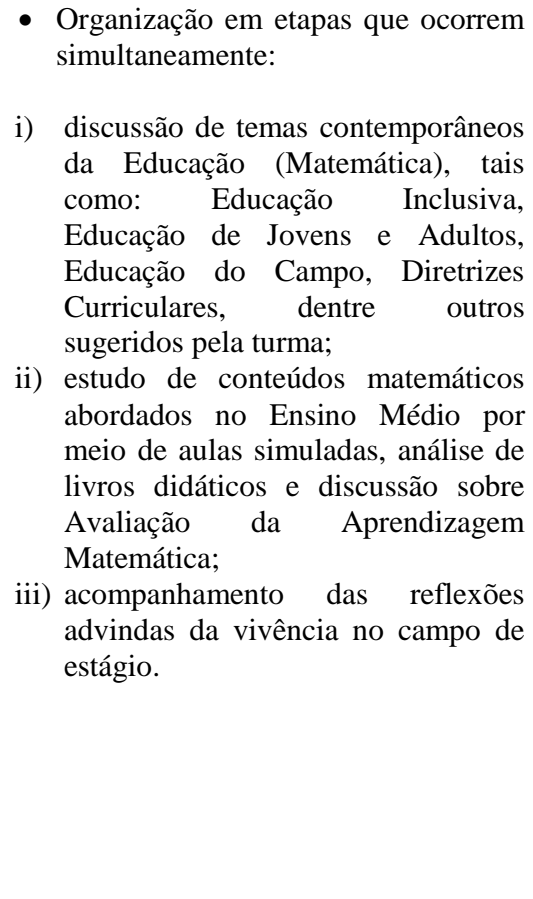 & $\begin{array}{l}\text { - Organização em etapas ocorridas de } \\
\text { modo fragmentado: } \\
\text { i) redução da quantidade de temas } \\
\text { discutidos e inclusão de temas antes } \\
\text { não previstos, tais como: Ensino } \\
\text { Híbrido, Educação Online, Educação } \\
\text { à Distância; } \\
\text { ii) manutenção do estudo de conteúdos } \\
\text { matemáticos do Ensino Médio por } \\
\text { meio de aulas simuladas com } \\
\text { limitação da interação professora - } \\
\text { estagiários devido aos recursos } \\
\text { utilizados (p. ex.: slides preparados } \\
\text { previamente) e análise de materiais } \\
\text { didáticos distribuídos pela SEC; } \\
\text { iii) contatos pontuais com os professores } \\
\text { regentes, não conhecimento do } \\
\text { espaço físico escolar, } \\
\text { reconhecimento da escola remota por } \\
\text { meio de formulários, vivência no } \\
\text { campo de estágio ao final da } \\
\text { disciplina, devido ao calendário } \\
\text { escolar, por meio de oficinas e não } \\
\text { apenas observação, o que não }\end{array}$ \\
\hline
\end{tabular}




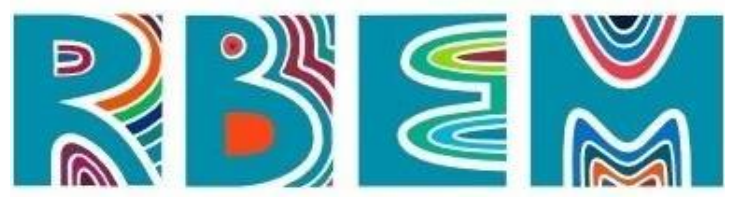

REVISTA BAIANA DE EDUCAÇÃO MATEMÁTICA

\begin{tabular}{|c|c|c|}
\hline & & $\begin{array}{lll}\text { favoreceu } & \text { reflexões } & \text { mais } \\
\text { aprofundadas. } & & \end{array}$ \\
\hline $\begin{array}{l}\text { ESTÁGIO CURRICULAR } \\
\text { SUPERVISIONADO EM } \\
\text { MATEMÁTICA IV } \\
\text { - Docência compartilhada no } \\
\text { Ensino Médio, fundamentada } \\
\text { por estudos, reflexões, } \\
\text { discussões, produção de } \\
\text { material e planejamento de } \\
\text { ensino e aprendizagem da } \\
\text { Matemática. } \\
\text { - Vivenciar e analisar relações e } \\
\text { interações existentes no } \\
\text { cotidiano escolar, referentes ao } \\
\text { processo de ensino e } \\
\text { aprendizagem da Matemática. }\end{array}$ & 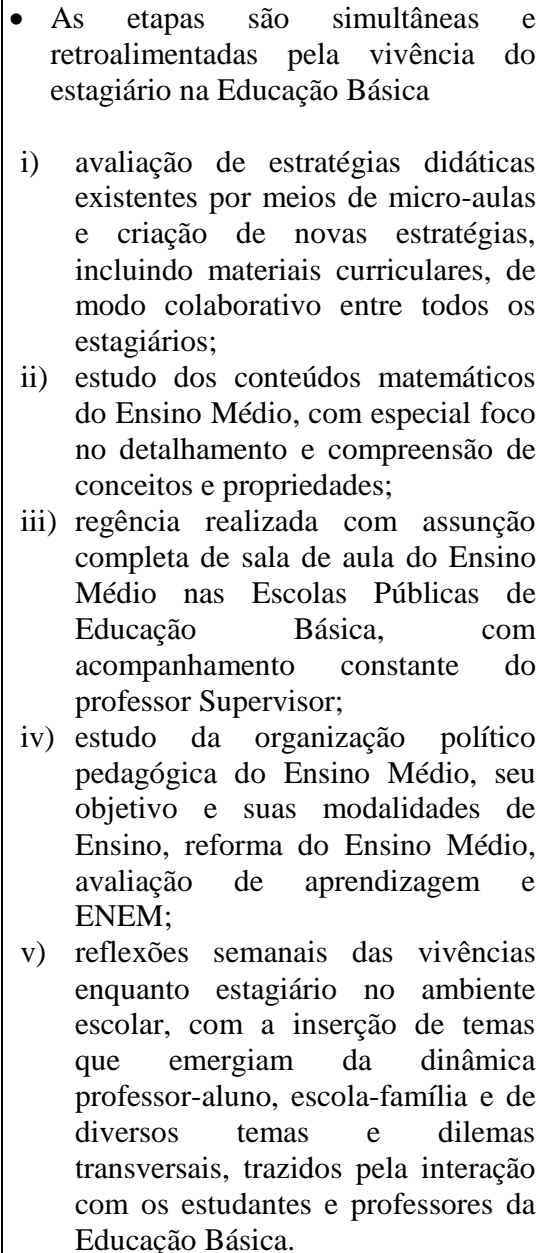 & $\begin{array}{l}\text { - Etapas estanques e intercaladas pela } \\
\text { necessidade constante de adaptação } \\
\text { do planejamento tanto da disciplina } \\
\text { de estágio, quanto da regência dos } \\
\text { estagiários } \\
\text { i) desenvolvimento de estratégias } \\
\text { didáticas para o ensino de } \\
\text { Matemática e estudo de conteúdos } \\
\text { matemáticos para o Ensino Médio, } \\
\text { apenas intermediado pelos } \\
\text { planejamentos das oficinas e } \\
\text { gravação de vídeo-aulas, adaptadas } \\
\text { ao formato remoto, dificultando a } \\
\text { criação e uso de materiais didáticos } \\
\text { manipuláveis, e a impossibilidade de } \\
\text { discussão detalhada e e } \\
\text { aprofundamento do estudo de } \\
\text { conceitos e propriedades; } \\
\text { ii) estudo da organização político } \\
\text { pedagógica do Ensino Médio, seu } \\
\text { objetivo e suas modalidades de } \\
\text { Ensino, reforma do Ensino Médio, } \\
\text { avaliação de aprendizagem e ENEM; } \\
\text { iii) regência realizada por meio de } \\
\text { Projeto que envolveu oferta de } \\
\text { palestras, cursos e oficinas, sem } \\
\text { possibilidade de interação e } \\
\text { planejamento de unidade para } \\
\text { assunção de uma turma regular de } \\
\text { Ensino Médio; a do estudantes da } \\
\text { iv) busca ativa dos } \\
\text { Educação Básica para participação } \\
\text { no Projeto, mas com limitações na } \\
\text { interação. }\end{array}$ \\
\hline
\end{tabular}

Fonte: As autoras

No quadro é possível observar que mesmo com uma revisão permanente e contínua do planejamento das atividades a serem desenvolvidas na universidade e nas escolas, não foi possível romper totalmente com aquilo que já se espera dos Estágios na modalidade presencial. Ou seja, o planejamento inicial tomou como base a experiência acumulada das professoras orientadoras com o ensino presencial, haja vista não termos experiência em educação não-presencial. Por outro lado, a sua reconfiguração ocorreu mediada por um processo de reflexão que envolveu o que discutíamos nos encontros síncronos e às realidades vivenciadas pelos estagiários e pelos estudantes da Educação Básica, em seus contextos. O fato de termos incluídos nos encontros síncronos discussões que geralmente não ocorrem em contextos presenciais (educação online, ensino híbrido, ensino remoto, EAD, pandemia, 


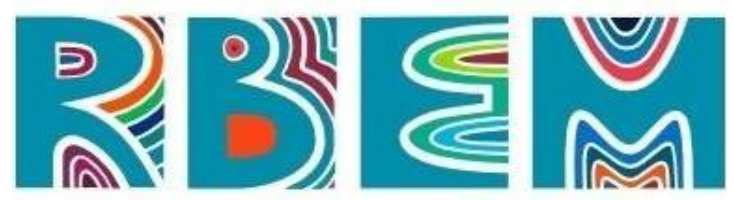

REVISTA BAIANA DE EDUCAÇÃO MATEMÁTICA

determinações curriculares para retorno às aulas), nos auxiliaram nesse processo de reconfiguração do planejamento.

Destacamos ainda que a familiarização com o uso de ferramentas virtuais pode ser um auxiliar no desenvolvimento de atividades no retorno presencial. Mas, reafirmamos que a dinâmica da sala de aula presencial, seja no Ensino Superior ou na Educação Básica, supera o modelo remoto na garantia de discussões, reflexões, convívio e, principalmente, na organização de um trabalho pedagógico que vise garantir um ensino com mais significado e interação na busca por uma aprendizagem mais efetiva.

\section{Referências}

ARAÚJO, Maria de Lourdes Haywanon Santos; MUSSI, Amali de Angelis; DE OLIVEIRA, João Danilo Batista. Política de formação inicial de professores: a trajetória da implantação da resolução CNE/CP 02/2015 na UEFS. Formação em Movimento, Rio de janeiro, v. 1, n. 2, p. 352-376, 2019. Disponível em:

<http://costalima.ufrrj.br/index.php/FORMOV/article/view/526>. Acesso em: 10 maio 2021.

ARRUDA, E. P. Educação Remota Emergencial: elementos para políticas públicas na educação brasileira em tempos de Covid-19. EmRede - Revista de Educação a Distância, v. 7, n. 1, p. 257-275, 15 mai. 2020.

BORUCHOVITCH, Evely. Autorregulação da aprendizagem: contribuições da psicologia educacional para a formação de professores. Psicologia Escolar e Educacional [online]. 2014, v. 18, n. 3, pp. 401-409. Disponível em: <https://doi.org/10.1590/2175-3539/2014/0183759>. Acesso em 25 jun. 2021

BRASIL. Ministério da Educação. Conselho Nacional de Educação. Parecer CNE/CES $N^{o}$ 009/2001. Diretrizes curriculares para formação de professores da educação básica, em nível superior, curso de licenciatura, de graduação plena. Brasília-DF: MEC/CNE, 2001

CADÓ, Iriana; BORSARI, Pietro. Medidas de amparo ao trabalho e à renda frente à pandemia do coronavírus: comparativo internacional. CESIT-Unicamp-Textos para discussão. Disponível em: https://www. cesit. net. br/medidas-de-amparo-ao-trabalho-ea-renda-frente-a-pandemia-do-coronavirus-comparativo-internacional. Acesso em: $22 \mathrm{de}$ abr 2021, v. 1, 2020.

CASTIONI, Remi et al. Universidades federais na pandemia da Covid-19: acesso discente à internet e ensino remoto emergencial. Ensaio: aval. pol. pub. Educ., Rio de Janeiro, v. 29, n. 111, p. 399-419, Jun 2021. Disponível em $<$ http://www.scielo.br/scielo.php?script=sci_arttext\&pid=S010440362021000200006\&lng=en\&nrm=iso>. Acesso em: 21 mai. 2021 


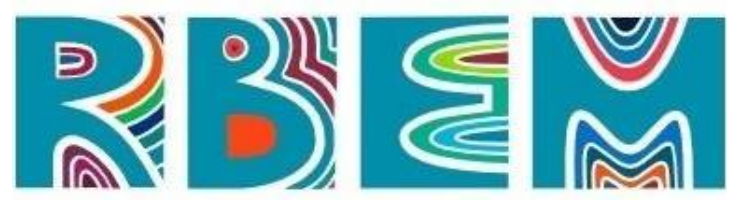

REVISTA BAIANA DE EDUCAÇÃO MATEMÁTICA

CHEVALLARD, Y. Sobre a teoria da transposição didática: algumas considerações introdutórias. Revista de Educação, Ciências e Matemática, v. 3, n. 2, maio/ago, 2013. Disponível em:

http://publicacoes.unigranrio.edu.br/index.php/recm/article/viewFile/2338/1111. Acesso em 26 abr. 2021.

CGI.br. - Comitê Gestor da Internet no Brasil. Pesquisa sobre o uso das tecnologias de informação e comunicação nos domicílios brasileiros: TIC Domicílios 2019. 2020. São Paulo: CGI.br. Disponível em: http://cetic.br/pt/arquivos/domicilios/2019/domicilios/. Acesso em: 23 abr. 2021.

FIORENTINI, Dario; LORENZATO, Sérgio. Investigações em educação matemática: percursos teóricos e metodológicos. 3 ed. Campinas: Autores Associados, 2009.

GIL, Antonio C. Métodos e técnicas de pesquisa social. 6 ed. São Paulo: Atlas, 2008.

GONÇALVES, Paulo Gonçalo Farias. A autorregulação da aprendizagem em matemática: um estado da questão. Anais III CONAPESC. Campina Grande: Realize Editora, 2018.

Disponível em: <http://editorarealize.com.br/artigo/visualizar/42823>. Acesso em: 25 jun. 2021

JUPP, Victor. The Sage Dictionary of Social Research Methods. Thousand Oaks: Sage, 2006.

LIMA, Maria. PIMENTA, Selma Garrido. Estágio e docência: diferentes concepções. Revista Poíesis. Volume 3, Números 3 e 4, pp.5-24, 2005/2006. Disponível em <https://www.revistas.ufg.br/index.php/poiesis/article/view/10542>. Acesso em: 15 mai. 2021

MARCON, Karina. Inclusão e Exclusão Digital em Contextos de Pandemia: que Educação estamos praticando e para quem? Criar Educação Revista do Programa de Pós-Graduação em Educação Unesc, v. 9, p. 80-103, 2020. Disponível em:

<http://periodicos.unesc.net/criaredu/article/view/6047>. Acesso em: 24 fev. 2021.

MOREIRA, Jose Antonio. SCHLEMMER, Eliane. Por um novo conceito e paradigma de educação digital onlinfe. Revista UFG, 20(26). 2020. Disponível em

<https://www.revistas.ufg.br/revistaufg/article/view/63438>. Acesso em 30 de abr 2021.

NOFFS, Neide de Aquino.; LIZARDO, Lilian de Assis Monteiro.; SILVA, Tânia Mara de Andrade Oliveira e. Estágio: o início da profissionalização docente. Laplage em Revista, [S. l.], v. 5, n. 1, p. p.121-131, 2019. Disponível em:

https://laplageemrevista.editorialaar.com/index.php/lpg1/article/view/436. Acesso em: 30 abr 2021.

PIMENTA, Selma Garrido.; ANASTASIOU, Léa das Graças C. Docência no ensino superior. 4 ed. São Paulo: Cortez, 2010.

PIMENTA, Selma Garrido; LIMA, Maria Socorro Lucena. Estágio e docência. São Paulo: Cortez, 2004. 


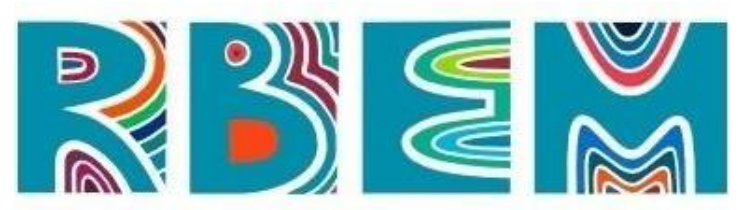

SANCHOTENE, I. J.; ENGERS, P. B.; RUPPENTHAL, R.; ILHA, P. V. Competências Digitais Docentes e o Processo de Ensino Remoto Durante a Pandemia da Covid-19. EaD em Foco, v. 10, n. 3, jan. 2021. Disponível em < https://eademfoco.cecierj.edu.br/index.php/Revista/article/view/1303 >. Acesso em: 23 abr. 2021

SANTOS, Edméa. Educação online para além da EaD: um fenômeno da cibercultura. Actas do X Congresso Internacional Galego-Português de Psicopedagogia. Braga: Universidade do Minho, 2009. Disponível em: <t12c427.pdf (udc.es)>. Acesso em: 23 abr. 2021.

TARDIF, Maurice. Saberes docentes e formação profissional. Petrópolis: Vozes, 2002.

UNESCO. COVID-19 impact on education. 2020. Disponível em:

https://en.unesco.org/covid19/educationresponse. Acesso em: 25 de mai. 2021

Artigo submetido em: 30/06/2021

Artigo aceito em: 19/08/2021 